\title{
The Economics of Customs Unions in the Commonwealth of Independent States
}

Constantine Michalopoulos

David Tarr
The World Bank

International Economics Department International Trade Division and

Russia and Central Asia Department June 1997
The Customs Union proposed for four members of the Commonwealth of Independent States (CIS) and the Free Trade Aree established among the 12 members of the CIS - are likety to lock those countries into the old technology of the former Soviet Union. The effects of such organizations. will be especially negative for the countries that have already established relatively liberal trade regimes. 


\section{Summary findings}

In the aftermath of the breakup of the Soviet Union, trade among the new independent states collapsed. To help reestablish interstate trade, the 12 members of the Commonwealth of Independent States (CIS) established a Free Trade Area. More recently, four members of the CIS - Belarus, Kazakstan, the Kyrgyz Republic, and Russia - agreed in principle to establish a Customs Union.

Michalopoulos and Tarr analyze the economic implications for potential members of establishing such a
Customs Union. They conclude that the dynamic effects of the Union (and the Free Trade Area) are likely to be negative, because they would tend to lock the countries into the old technology of the former Soviet Union. The static effects would tend to be mixed but would be more harmful to countries that have already established relatively liberal trade regimes with lower average and less-differentiated tariffs than the common external tariff contemplated by the proposed Customs Union.

This paper - a joint product of the International Trade Division, International Economics Department, and the Russia and Central Asia Department - is part of a larger effort in the Bank to analyze the effects of different trade regimes in countries in transition. Copies of the paper are available free from the World Bank, $1818 \mathrm{H}$ Street NW, Washington, DC 20433. Please contact Minerva Pateña, room N5-048, telephone 202-473-9515, fax 202-522-1159, Internet address mpatena@worldbank.org. June 1997. (30 pages)

The Policy Research Working Paper Series disseminates the findings of work in progress to encourage the exchange of ideas about development issues. An objective of the series is to get the findings out quickly, even if the presentations are less than fully polished. The papers carry the names of the authors and should be cited accordingly. The findings, interpretations, and conclusions expressed in this paper are entirely those of the authors. They do not necessarily represent the view of the World Bank, its Executive Directors, or the countries they represent. 


\title{
THE ECONOMICS OF CUSTOMS UNIONS IN THE COMMONWEALTH OF INDEPENDENT STATES
}

\author{
by \\ Constantine Michalopoulos \\ and \\ David Tarr
}

JEL categories: F15; P33.

Address correspondence to:

David G. Tarr

Room N-5-037

The World Bank

1818 H. St., N.W.Washington D.C. 20433

E-mail: DTARR@WORLDBANK.ORG 



\section{The Economics of Customs Unions \\ in the Commonwealth of Independent States}

Constantine Michalopoulos and David Tarr ${ }^{1}$

\section{Introduction}

In the aftermath of the break-up of the Soviet Union, trade among the new independent states collapsed. Estimates vary, but the drop in volume terms may have been as much as $50 \%$ between 1992 and 1995 (see table 1). We have discussed the reasons and the consequences of this drastic decline elsewhere (Michalopoulos and Tarr, 1994; 1996).

The three Baltic countries decided, early on, to reorient their trade to Europe and the rest of the world; and all three have signed association agreements with the European Union. The other twelve countries (members of the Commonwealth of Independent States (CIS)), attempted, mostly unsuccessfully, to maintain trade with each other through a variety of policy interventions, including through the establishment of a Free Trade Agreement (FTA). In 1995 three countries, Belarus, Kazakstan and Russia established a customs union which the Kyrgyz Republic agreed to join in 1996.

The purpose of this paper is to analyze the economic implications of a customs union among transition economies, such as the one established by these four countries, for both existing and prospective members. The next section of the paper describes in broad terms the current trade regimes of the CIS, including the arrangements that govern trade with each other. The third section analyses the economic effects of the customs union, in part through the use of a partial equilibrium model described in detail in the appendix. The focus is on the effects of joining the

1 The authors are, respectively: Senior Advisor in the Russia and Central Asia Department, the World Bank; and Lead Economist, International Economics Department, The World Bank. Helpful comments on an earlier draft were received from Peter Hansen and Maurice Schiff of the World Bank, Svyatoslav Perfilov of the CIS Interstate Economic Committee and international trade representatives of the 17 transition economies who participated at the EDI seminar on Trade Policy in Transition and WTO Accession, January 31-February 6, 1997, Vienna, Austria. We thank Minerva Patena and Maria Luisa de la Puente for logistical support. The views expressed are those of the authors and not necessarily those of the World Bank or those acknowledged. 
customs union for countries which have not done so. As most CIS members are applying for accession to the WTO, this section also draws some implications of the customs union for WTO accession. The last section summarizes the policy conclusions and implications of the analysis. While the analysis focuses on the CIS countries, some of the findings may be of relevance to other countries in transition--for example, among the countries of the former Yugoslavia, that are considering the establishment of similar arrangements.

\section{The Trade Regimes}

While the trade policy framework continues to be evolving and varies considerably among countries, the following main features characterize the trade regimes of CIS members:

On the import side, most countries have so far avoided the establishment of quantitative restrictions or licensing. But protectionist pressures are rising and leading to the imposition of such controls in some countries (e.g., Uzbekistan) or sectors (alcoholic beverages-- in Russia). The tariff regimes vary considerably, but on the whole countries have established few tariffs exceeding $30 \%$. Some countries have low and uniform tariffs, e.g., Armenia's maximum tariff is $10 \%$ and the Kyrgyz Republic has a 10\% uniform tariff); while in others the range goes up to $100 \%$ for a few items. In Russia, the average is about $13-14 \%$ with a range from 0 to $30 \%$ for most commodities, with some selected items considerably higher (see table 2 for details at a somewhat aggregated level).

On the export side, there has been significant dismantling of export controls in most countries; but controls of exports through state trading continues in some key exportables (cotton, oil and natural gas).

Trade with each other, is in principle free under the terms of the FTA. Imports are duty free, but it appears that export and foreign exchange controls in practice limit trade among some of the countries. Weaknesses in the payments systems continue to hamper trade, leading to continuing use of barter; but the previous state to state barter agreements have been by and large eliminated. Many countries have established a mixed VAT system: "origin" based for CIS trade 
and "destination" based with regard to the rest of the world. This means that with respect to CIS countries, imports are not taxed but domestic producers pay the VAT regardless of whether the good is exported or sold domestically. For the rest of the world, imports pay the VAT but exports are zero rated.

The Customs Union members negotiated a common external tariff based on the Russian tariff. But in the course of 1996, the three original members unilaterally introduced modifications to the external tariffs they applied to some commodities (Rietzler and Usmanova, 1996); also, as of the time of this writing, the Kyrgyz Republic had not taken any steps to introduce the common external tariff but instead continued to apply a uniform $10 \%$ tariff to imports from the rest of the world. All four countries are applying to the WTO on the basis of individual tariff schedules rather than as a custom union. Thus, at present, strictly speaking, there is no common external tariff for the Customs Union. But the agreements are still in place and the governments may pursue further steps towards their full implementation.

\section{The Effects of Customs Union}

There are two kinds of effects of customs unions, static and dynamic. The static effects relate to the impact of the establishment of the customs union on welfare. The analysis in this instance focuses on a comparison of the welfare of a country or groups of countries before and after the establishment of the customs union; thus the analysis is one of comparative statics. The dynamic effects focus on the impact the customs union on the rate of output growth of a country or countries in the medium term ${ }^{2}$ Many analysts have noted (Winters 1996) that supporters of customs unions and other regional preferential arrangements frequently find that the static welfare effects are typically small and possibly negative. They then focus on the potential dynamic benefits, which however, are difficult to define and even more difficult to measure.

$2 \quad$ It is important to note that output growth can not be equated to welfare growth, as some of the mechanisms that may result in increasing the rate of growth of output in a future period may involve reduced consumption and welfare in the present. 
In the case of the CIS countries, there is already a FTA among all members as well as a Customs Union (CU) among some of them however modified by specific exceptions for variation from a common external tariff. Hence the analysis of both dynamic and static effects has to compare the advantages and disadvantages of joining this specific customs union not just any one, and assumes that in principle the alternative to joining, is continuation of the FTA among the CIS; but the implications of a different alternative, under which countries that do not join the $\mathrm{CU}$ are excluded from the FTA area, also briefly examined.

\section{Static Welfare Effects}

The principal impact of joining the customs union would be to replace the external tariff of each of the countries with the common external tariff of the customs union. In general, under these circumstances the benefits of joining the $\mathrm{CU}$ would depend to a considerable extent on the height and structure of each of the countries external tariff compared to that of the Customs Union external tariff. While in practice a Customs Union external tariff may not be in place at present, for purposes of analysis, the Russian tariff is a good proxy of the Customs Union external tariff that had been negotiated and will be used for the discussion in this paper. If a country such as Armenia or the Kyrgyz Republic with lower external tariffs were to substitute the Russian tariff for its own tariff structure, it would increase its unweighted average tariff to 13-14 percent (see table 2). More importantly, assuming that following accession of new members, the common external tariff is not changed, the Russian tariff exhibits considerably more dispersion compared with the tariff for some of the countries (typically between 0 and 30 percent),${ }^{3}$ meaning that for selected highly protected products in Russia, the tariff would increase significantly. For other countries, adopting the common external tariff would mean actually reducing their average tariff.

Starting with Jacob Viner (1950), international trade economists typically analyze preferential trade arrangements, whether members of a FTA or a CU, in terms of trade creation

3 See table 2 for a listing of the Russian tariff by sector. Since an aggregation was performed in table 2, the Russian tariff is higher for some tariff lines within the aggregates shown than for the sector as a whole. 
and trade diversion. Trade creation in a product occurs, when additional imports come from partner countries which displace sales of inefficient domestic producers and these imports are at least as cheap as imports from non-partner countries. Trade creation results in improved welfare for the importing country for much the same reasons as increased trade improves a country's welfare. On the other hand, trade diversion occurs when suppliers in the rest of the world (who continue to face tariffs) are more efficient than partner suppliers, but additional partner country imports displace the more efficient suppliers. Trade diversion is typically (but not necessarily) welfare reducing since the home country must pay more to import the product from the less efficient partner country suppliers.

Although the general theory of regional trading arrangements is quite ambiguous in its conclusions, we believe some definitive conclusions are possible with respect to the specific customs union under consideration, at least for some of the CIS countries. Since the partner countries in the potential customs union already have tariff free access to the other CIS markets under the Free Trade Agreement, prices in these countries' markets cannot fall as a result of the customs union, i.e., there will be little welfare gain from trade creation. Whatever trade creation would occur, would come from third country suppliers in those products where the current external tariff in the country is higher than that of the Customs Union external tariff. Since welfare costs from a tariff increase with the square of the tariff rate, net welfare effects are little impacted by reductions in tariffs by a few percentage points say, from ten to seven percent. Rather what is crucial to the welfare effects are the changes that involve significant tariff increases. 4

Countries with Lower Tariffs Than in the Customs Union. Prospective partner country suppliers will have the potential, under the higher tariffs of the customs union, to raise prices to consumers in other CIS countries by the amount of the tariff preference over rest of world imports. In the model we present in the appendix, we assume that they will do so. A principal reason we believe they will do so is our judgment that advocates of the customs union propose it 4 See Morkre and Tarr (1980, chapter 2) for details. 
as a means of expanding protection for inefficient domestic industries throughout the CIS. That is, the customs union is an import substitution strategy for inefficient industries, where the structure of the tariff is high in those industries that exist in the customs union, especially in Russia. In the appendix, we elaborate some additional reasons why we believe they will do so. Thus, a key assumption of our model is that prospective members of the customs union face upward sloping supply curves from partner country suppliers who will raise prices by the extent of the tariff. Moreover, since these countries have tariff free access to markets of the members of the customs union and to Russia in particular, the exporters from a CIS country joining the CU will not obtain improved access to the Russian market, which is by far the dominant market in the customs union. Thus, for countries like the Kyrgyz Republic and Armenia with already liberal external tariffs or others like Georgia and Moldova which are also pursuing generally liberal trade policies and assuming the common external tariff is not changed following their accession, the usual tradeoffs that must be considered in the evaluation of a preferential trade arrangement (trade diversion versus improved access and trade creation) do not apply. Thus, the CU would virtually result in pure trade diversion (see the appendix for details).

High tariff protection for such small economies is generally very inefficient and costly. Protection prevents the transmission of world prices to the economy and thereby prevents market signals from inducing resource reallocation to areas of comparative advantage in the economy. Experience has shown that over time, countries with high protection generally grow more slowly than those with low protection (see, e.g., Thomas, Nash and others, 1991; and Sachs and Warner, 1995). Moreover, we show in the appendix that increasing an external tariff within the framework of a customs union with Russia and the other partners for a small CIS country, is much more costly than simply raising tariffs, without preferential treatment to the customs union members. In fact, in this example the customs union will be several times more inefficient and costly to the small country than simply raising tariffs to the rest of the world in a non-preferential manner. 
Joining the customs union with a common external tariff such as that previously negotiated is so costly for several reasons: First, partner country suppliers can raise prices under the tariff protection they receive from preferential protection. Then for the quantities previously purchased from partner country suppliers, consumers in member countries with a previously lower external tariff will likely pay higher prices (excluding the tariffs) to partner country producers than they were paying prior to participation in the customs union, i.e., there is an adverse terms-of-trade effect on the initial quantities purchased from partner country suppliers. Second, since rest of world imports are subject to a higher tariff, there will be a diversion of sales away from rest of the world suppliers toward partner country suppliers. This trade diversion entails two costs: (a) since the importing country does not collect any tariff revenue on imports from partner countries, there is a loss of the tariff revenue on these trade diverting imports; ${ }^{5}$ and (b) excluding the tariff, consumers will have to pay higher prices to partner country suppliers than they were paying to rest of world suppliers prior to participation in the customs union.

In their comprehensive theoretical treatment, Bhagwati and Panagariya (1996) describe a model in which partner country suppliers have perfectly elastic supply curves. This situation might be expected to apply if a country is forming a preferential trade area with a very large market, such as the European Union or NAFTA, because competition among many suppliers in the large market results in flat supply curves to the prospective new member country. In this case, there is a much larger likelihood of the preferential trade area being welfare increasing since the new member will not suffer a terms-of-trade loss on its purchases from the suppliers from the large market.

Countries with Higher Average Tariffs Than in the Customs Union. For countries with a higher average external tariff than that of the $\mathrm{CU}$, the results are more ambiguous. On the one hand, in converting to the common external tariff, since the average tariff is lower than in the

5 The loss of tariff revenue due to the diversion of imports away from the rest of the world is a loss of welfare to the home country, since it will have raise tax revenue from other sources to offset the loss of government revenue. This is in contrast to a reduction of tariffs multilaterally, where consumers benefit from a reduction in the price they pay, and the increase in consumers' surplus offsets the loss of tariff revenue. 
home country, there will be a number of products where the external tariff will be reduced. Then there will be a welfare gain on those products where the external tariff is lowered because there will be some trade creation from additional imports from rest of the world suppliers (partner country suppliers already have tariff free access due to the FTA so no additional trade creation is possible from CIS partners). On the other hand, the negotiated tariff of the CU is not uniform; rather it favors production of those products already produced in the CU. Even in countries with higher average tariffs than in the $\mathrm{CU}$, their tariffs typically favor their home production.

Substitution of the CU tariff will shift the tariff structure so that it favors the producers of the CU, i.e., tariffs will be high on the products produced in the $\mathrm{CU}$ and low on the products produced in the home country, and it is likely that even in countries with higher average tariffs, they will have to raise their external tariffs on many products produced in their partner countries. This will allow partner country producers to charge higher prices under the protection of higher tariffs on third country producers, a significant welfare loss that is likely to dominate. A choice available to a country in these circumstances is to lower its tariff on third countries, without joining the CU. This option offers the gains from the trade creation on the products where the external tariff is being lowered, without the losses of the trade diversion from having to pay higher prices to inefficient partner country suppliers.

Russia, Kazakstan and Belarus. Finally, briefly consider the welfare impact on Russia, Kazakstan and Belarus, the members of the Customs Union which had adopted the common external tariff. Since the tariff structure favors production in these countries, then as more countries join the Customs Union, in the short run producers in these countries will gain additional profits and exports from the additional protection they receive against rest of world imports in the new partner country markets. Since the costs of protecting home producers will be borne in part by consumers in partner countries, the strategy has an initial appeal in the countries whose producers receive the high protection. But, because the benefits of a liberal trade regime to consumers are dispersed widely (presenting a free-rider problem where it is not typically worth it to individual consumers to lobby their governments for liberal trade actions) while the benefits of 
trade protection are concentrated in the industry receiving protection (which provides an incentive for the industry to lobby its government for protection), the kinds of preferential trade areas that will typically arise are those which are trade diverting (see Grossman and Helpman (1995)). Thus, in order for the existing members of the Customs Union to convince additional members to join, or at least to remain members over time, it is likely that the tariff structure will have to change in a way that offers protection to producers of other CIS countries, i.e., the existing members will have to offer protection in their markets to high priced products produced in nonmember CIS states. A country will not participate in a Customs Union if the Customs Union offers neither enhanced protection for its producers nor widespread benefits for its consumers. 6

If the external tariff is adjusted to accommodate the inefficient producers of new members, although some of the producers of the existing member countries may still gain from a wider Customs Union, the benefits to the countries as a whole are going to be reduced and countries could become net losers. That is, the short-run gains to existing producers mask potential longer term costs of not opening up trade to the rest of the world. It is likely that the entire CIS is not collectively large enough to approximate world market efficiency in most products. Thus, a strategy of widening the protection of domestic producers through a Customs Union of a set of the CIS countries, is really an import substitution policy through protection on a slightly larger scale, a strategy that has retarded growth in many countries (see, e.g., Bhagwati and Krueger, 1973; Sachs and Warner, 1995; and Thomas, Nash and others, 1991). ${ }^{7}$

6 We have already observed the manifestation of these problems, as Kazakstan and Belarus have selectively suspended application of the common external tariff, i.e, the trade diversion costs were evident to the parties (see Rietzler and Usmanova, 1996, p. 30)

7 If the common external tariff is renegotiated to reflect the interests of the non-member countries, then the static welfare economics for non-member countries will not be as adverse as depicted in the sections above treating the welfare economics of the non-member countries. Nonetheless, liberalization toward the world as a whole would remain the preferred strategy to joining the Customs Union, since, as just discussed, even the CIS as a whole must be wary of an import-substitution strategy. 


\section{$\underline{\text { Revenue Effects }}$}

Due to the potential impact on the fiscal deficit, macro stabilization and inflation, governments must also be cognizant of the impact of preferential trade arrangements on their revenues. In this section, we examine various aspects of this question for the CIS countries.

Tariffs. Joining the customs union is likely to have negative revenue implications on individual new members. As there will continue to be no tariffs on trade within the customs union, to the extent that rest of world imports are displaced, tariff revenue will be lost to the customs union. In addition, despite the fact that the customs union agreements stipulate that the tariff revenue will go to the country to whom the imports are destined, one can not overlook the potential administrative problems associated with obtaining tariff revenues from the customs offices of other member countries, especially given the weakness in tax reserve collections in all these countries. And there are other reasons to believe that revenues of imports from the rest of the world will be diminished. There are central administrative institutions of a customs union that will have to receive funding. Funding for the administration of the customs union or any centralized programs is typically done out of tariff revenue collected by the customs union.

Excise Taxes. Accession to the customs union will increase pressure on members to harmonize excise tax rates. These rates are presently rather diverse both within the CU countries and potential members. The tax revenue implications of unified rates would have to be assessed in each case individually.

Value Added Taxes. The dominant practice among the CIS countries is to apply the value added tax (VAT) on a mixed basis. That is, for trade outside of the CIS, imports are taxed but exports are not, the "destination" system. For trade within the CIS, exports are taxed but imports are not, the "origin system." Participation in the customs union will require a value added tax that is harmonized with the system applicable in the customs union, i.e., the current mixed system. Berglas (1981) has shown that under certain assumptions (including flexible exchange rates) the origin or destination systems are equivalent and do not tax the trade regime if designed properly. Since the VAT rates of most CIS are approximately equalized, the allocation of real resources 
and trade flows among the other CIS countries is not seriously affected, but it is important to harmonize these taxes within a mixed system to avoid arbitrage and distortions. ${ }^{8}$

What is more likely to be a problem with a mixed VAT system is the allocation of tax revenues. Even if the VAT rates are harmonized, countries with a trade deficit within the customs union and a trade surplus outside the customs union will experience an adverse transfer of VAT tax revenues toward the partners in the customs union with the opposite trade pattern. To illustrate, suppose the trade of Azerbaijan is balanced overall, but it imports exclusively from, say Russia, and exports exclusively outside the customs union, and that Russia has the opposite trade balance.

Since the destination system applies on trade outside of the CIS, and the origin principle applies on trade within the CIS, Azerbaijan would collect no VAT tax revenues (neither on its imports nor its exports), and Russia would collect all the VAT revenue on trade (Russia collects VAT on both its exports to Azerbaijan and its imports from the rest of the world). Thus, even though the mixed VAT system would not change relative prices and is therefore non-distortionary because there is no impact on the allocation of resources, in this example it would represent a transfer of VAT revenues from Azerbaijan to Russia.

\section{Dynamic Effects}

In general, there are two basic ways in which the rate of output growth can increase: First through a faster growth of factor inputs and second through increases in the growth of total factor productivity. Assuming no changes in population growth and in labor force participation rates, the growth of factor inputs essentially boils down to the rate of investment in human and physical capital. Total factor productivity on the other hand is thought to be dependent in the medium and long term on improvements in technology and knowhow. More generally, access to a diverse mix of products including modern technology appears to be very important for the growth process (see

8 The apparent (rather than real) incentives of the mixed system may present difficulties politically since it appears to provide an incentive to import from the CIS (thus avoiding VAT on imports) and export to non-CIS countries (where no VAT is paid). 
e.g., Romer, 1994). New and diverse technologies are constantly appearing and these new technologies allow an increase in the productivity of both capital and labor. ${ }^{9}$

The question that needs to be addressed then is how a customs union among the CIS countries will affect output growth through its impact on access to technology that enhances productivity and through its effects on the rate of investment in human and physical capital (see de Melo, Panagariya and Rodrik, 1993). There is some evidence that developing countries total factor productivity is positively related to the access of technology and knowledge embodied in imports from developed countries (Coe and Helpman, 1995; Coe, Helpman and Hoffmaister, 1995). In the case of CIS and other transition economies, access to diverse and modern intermediate products from world markets appears especially crucial as these economies attempt to transform themselves from an industrial structure that was inherited from the era of the former Soviet Union, i.e., that was outdated and frequently not based on comparative advantage. It is very important that these countries move away from reliance on technologies that are available only in the countries that were part of the former Soviet Union, since the most dynamic and modern technologies are found elsewhere. Yet, tariff protection for products that are produced in the customs union will discourage the introduction of new products and technologies from outside the customs union and free trade area, technologies that would boost the growth and development of the CIS members. Thus, on the question of enhancing growth through improvements in total factor productivity the effect of the customs union (and for that matter of the exisitng free trade area) on all its members is likely to be very negative.

There are several ways through which a customs union could affect the rate of investment in member countries: (a) through a change in tariffs and hence in the cost of imported capital equipment that changes the rate of return on investment and the rate of capital accumulation; (b) through affecting the financial system and the overall stability and effectiveness of economic policies that improve the climate of investment; (c) by providing an incentive to foreign direct

9 See Rutherford and Tarr (1996) for a model quantifying this effect. 
investment to locate and produce in the countries of the Union as opposed to exporting goods and services( Winters 1996).

Unfortunately, it is difficult to make a credible case that these effects would be positive in the case of a customs union in the CIS. First, it is likely that the cost of imported capital would actually increase especially for some of the smaller members, as they could obtain capital goods more cheaply from third countries. Second, while there are plans for greater integration of the financial systems and economic policies of members which may have a positive impact on the climate of investment in the future, there is very little chance that any of this will happen in the immediate future. In fact, premature integration without adequate multilateral institutions may resurrect some of the problems of the recent past which contributed to instability. For example, the common ruble area of 1992-1993, without monetary coordination of the multiple central banks was a root cause of inflation and the problems of trade (see Michalopoulos and Tarr, 1992; 1993). The key challenge in all countries is how to improve the national environment for private sector development through the establishment of policies and institutions ( for example better enforcement of contractual obligations) that improve the investment climate-policies that may best be pursued unilaterally in the near term. Third, it is possible that as result of the establishment of the customs union, there may be a positive effect on foreign investment that comes in to "jump" the common external tariff. How big this effect will be is hard to predict simply because there are so many other factors that constrain the inflow of foreign direct investment which countries need to address first and which are likely to have a far greater impact on foreign direct investment than the stimulus provided by the establishment of a customs union. More importantly, foreign direct investment which is in response to tariff jumping can cause the welfare and growth rate of the capital importing country to decline (see Brecher and Diaz-Alejandro, 1977). The reason is tht foreign investment responds to the private return to capital, and the foreigners will repatriate profits based on their private returns; but when the sector is highly protected, the social return to investment in the sector is much lower than the private return. 
In sum, while the dynamic effects of establishing or joining a customs union and of the exisiting Free Trade Area in the CIS are difficult to demonstrate, they are likely to be negative, especially because of the adverse effect of the preferential arrangements on technology and productivity improvements.

The Threat of the Loss of the Free Trade Agreement

In the event that a CIS country fails to join the customs union, there is some possibility that the members of the customs union would apply the common external tariff to the exports of that CIS country; that is, they may revoke their Free Trade Agreements. Although we must be cautious since the effects will vary from country to country and we do not have precise estimates, the net welfare impact of participation in the Free Trade Agreement is likely to be negative for most CIS countries; consequently, the threat of exposure to the common external tariff of the customs union is not an event that should be feared for most CIS countries.

The reasons are as follows: If Russia, Kazakstan and Belarus, withdraw from the Free Trade Agreements and apply the negotiated common external tariff of the customs union to exports from the other CIS countries, there would be economic impacts on both the imports and the exports of these CIS countries. Regarding imports, as explained in detail in the appendix, applying tariffs on imports from former partner countries in the CIS results in displacement of partner country imports by rest of world supply. This results in a gain in tariff revenue on these sales. Moreover, since partner country suppliers are likely, in many products, to lower their prices to the extent of reduction of the tariff on rest of world products (since marginally inefficient partner country suppliers will be forced out of the market as competition from rest of world producers becomes more intense), CIS consumers will be able to pay less to partner suppliers by the amount of the tariff, and this is a gain to their economic welfare. Moreover, permitting efficient imports from the rest of the world as opposed to preserving inefficient imports from partners in the former Soviet Union, is very productive in terms of breaking away from the outdated and inefficient technology of the Soviet past. 
Weighed against this potential gain in welfare from application of tariffs on imports in the CIS is the loss in welfare from lost preferential access to the markets of countries in the Customs Union. Exporters from the CIS countries outside the Customs Union would no longer be able to obtain higher prices than producers from the rest of the world on exports to the countries in the Customs Union, since like exporters from the rest of the world, their exports would also be subject to the tariff. But since the negotiated tariff of the Customs Union is based on the Russian external tariff, it tends to be high in those items important to Russian producers. That is, products important to the exports of the CIS tend to be inputs into production in Russia and therefore have relatively low tariffs in the Customs Union. Although we must again be cautious since this effect will vary from country to country and we do not have precise estimates, this implies that most CIS countries outside Russia, Belarus and Kazakstan likely derive little terms of trade gain on their exports to the Customs Union, from the fact that they are in the Free Trade Agreement. That is, most CIS countries perhaps with the exception of Ukraine, would likely be able to sell the vast majority on their products in the same markets with small losses losses that are considerably smaller than the losses suffered by their consumers from having to pay higher prices to the exporters from the Customs Union. Moreover, the dynamic effects of the free trade area could also be negative, for all its members.

It would be desirable for CIS exporters to find alternate marketing channels outside of the CIS Customs Union countries. This would reduce dependence on a limited number of countries for markets and transportation facilities. Absent Free Trade Agreements, it will become even more imperative for exporters from the CIS to find alternate markets and marketing channels. Moreover, while finding new markets outside of the Customs Union countries may require a difficult adjustment period, the experience of the Baltic countries between 1992 and 1994 demonstrates that rapid adjustment is possible. 10

10 In earlier papers (Michalopoulos and Tarr, 1992; 1993) we argued in favor of temporary Free Trade Agreements among the newly independent states. The argument was based on easing transition costs due to the heavy interlinkages of the production structures in the countries of the FSU. The justification for the continuation of the Free Trade Agreements on the basis of easing the adjustment costs, however, becomes progressively weaker over time and the importance of integrating with the rest of the world becomes more important over time. These concerns were 
Accession to the World Trade Organization

Most CIS members have begun the process of accession to the World Trade Organization (WTO). The WTO permits custom unions as long as they meet two basic requirements: (a) they cover substantially all trade among the partners; and (b) do not result in an increase in the level of protection to the outside world relative to before the establishment of the CU. In the past these WTO provisions have been applied quite flexibly and it is quite possible that the CU negotiated among the four CIS members would meet the WTO standards. Thus participation in this customs union will not by itself prevent an individual country from joining the WTO. The question is whether it would be useful for individual countries to enter the CU and join the WTO as part of the $\mathrm{CU}$ or individually. Judging from recent experience, it will complicate the accession process to the WTO of individual CIS members to present an accurate picture of its trade regime to the members of the WTO "working party" who will be charged with the negotiation of their accession if they were to move to make commitments in joining the $\mathrm{CU}$ before they become members of the WTO. That is, the WTO working party would perceive that the present trade regime of the CIS country will be changed significantly in the future if it joins the Customs Union. Perhaps it is for this reason that Belarus, Kazakstan, the Kyrgyz Republic and Russia are applying to accede to the WTO on an individual basis, not as members of a CU.

\section{Conclusions and Recommendations}

1. For small CIS countries, with relatively open trade regimes, joining the Customs Union that has been established by several CIS members could be economically quite costly. These costs could be mitigated, but probably not fully offset, if as a consequence of the entry of new members, both the average level and the dispersion of the previously negotiated external tariff of the customs union were reduced. For these countries, maintaining an open trade regime without

reflected in our weakened endorsement of the Free Trade Agreements in Michalopoulos and Tarr (1994), and our considerable reservations toward them in Michalopoulos and Tarr (1996). 
preferences is the best policy that maximizes welfare and growth prospects. It will also facilitate entry into the WTO, a key objective for these countries' trade policies.

2. Even for the existing customs union members, and for others with more restrictive trade regimes than those of existing members, preferential arrangements that provide strong incentives to orient trade towards partners in the former Soviet Union contain significant long term risks. The main risks are that the preferences (through customs union or free trade arrangements) lock in traditional technologies and production structures, reduce innovation and competition, and hence result in inefficient industries that absorb scarce resources that could be better used elsewhere.

3. The discussion has focused on preferences and a specific customs union arrangement among CIS countries. But it has relevance for preferential arrangements, including customs unions, that might be considered in the context of other country groupings in the CIS as well as in transition economies in Eastern Europe, e.g. former Yugoslavia. In this case as well, the main problems would arise from lack of competition and the absence of dynamic technology. The discussion is not intended to apply to countries in transition joining the EU, where different circumstances prevail which improve the prospects for economic benefits.

4. The key difference between preferential arrangements among CIS members and other preferential arrangements (NAFTA, the EU) is that in the latter the markets are large enough to promote competition and encourage the flow of new technology which increase the probability that distortions introduced through preferences are more than offset by new trade creation and the dynamic effects of investment embodying new technology.

5. We had advocated preferential arrangements for CIS members as useful transitional devices to mitigate the severe disruption of trade among the new independent states in the aftermath of the breakup of the Soviet Union (Michalopoulos and Tarr, 1992; 1994). Although based on duration of unemployment measures, two years appears to be a sufficient period of adjustment in market economies, ${ }^{11}$ there is no standard period for adjustment or transition; and the 11 See S. Matusz (1997) for a survey. 
breakup of the Soviet Union clearly created unprecedented disruption which may have warranted a greater adjustment period. The new independent states have had five years to adjust to international competition. Given the inherited burden of inefficiencies that plagues a sizable portion of CIS industry, there are serious costs of continuing preferential arrangements indefinitely, and integrating more closely through a customs union at this time appears ill-advised. 


\section{Appendix \\ Model to Evaluate the Consequences of Joining the Customs Union}

In this appendix, we develop a simple partial equilibrium model to assess the consequences of adopting the common external tariff, where the common external tariff is higher than the initial tariff. The model would apply rather broadly to countries with low tariffs, such as the Kyrgyz Republic and Armenia. The model would also be relevant for many products in countries with higher tariffs on average than the Customs Union tariff. Since the Customs Union tariff is not uniform, there are many products where the tariff in the Customs Union exceeds the home country tariff. The model is an extension of the model of Bhagwati and Panagariya (1996) and is shown in figure 1. A basic description of these techniques may be found in Morkre and Tarr (1980).

Demand. We refer to the home country as country A. The figure shows the demand for imports in country A for a representative product group, assuming for simplicity that imports from various sources are homogeneous. Demand for the domestic good (assuming there is domestic production) would be depicted on a separate diagram but (assuming otherwise undistorted domestic markets) we may calculate welfare effects from the demand for imports diagram.

Rest of World Supply. The rest of the world, denoted R, (outside the customs union) is assumed to be large in relation to country A considering membership and hence the supply curve from the rest of the world for any product is depicted as a perfectly elastic flat supply curve at the world price of the product $P_{R}$. In the initial equilibrium, the supply curve from the rest of the world is represented by $P_{R}(1+t)$, reflecting the fact that since rest of world suppliers must receive $P_{R}$ to be induced to supply the product, consumers in country A must pay $P_{R}$ to foreign suppliers plus $t^{*} \mathrm{P}_{\mathrm{R}}$ to the government in tariffs. Converting to a higher tariff of the customs union (weighted average of 13-14 percent) implies that the supply curve of the rest of the world increases to $P_{R}\left(1+t^{\prime}\right)$. 
Partner Country Supply. The group of countries who are in the Customs Union are denoted country $\mathbf{P}$, for potential partner countries. For this representative product, the aggregate supply curve to country A from all countries that are potential partners with A in the Customs Union (such as Russia and Kazakstan) is depicted as $\mathbf{S}(\mathrm{P})$. Imports from these countries are not subject to a tariff. If tariffs were imposed on imports from these countries, it would be necessary to pay a tariff inclusive price to attract the supply. That is, the appropriate supply curve would be a function of the tariff inclusive price. Then the tariff supply curve to country A including the tariff would shift up and to the left. In figure 1 , we write this as $S[P /(1+t)]$.

In figure 1, we have depicted partner country supply as upward sloping. One reason why this could occur is that partner suppliers have a factor of production in limited supply that implies that it produces at increasing costs within the range of outputs under consideration. This might be because of continuing bottlenecks for selected inputs. Even though the market in country A may be small, the partner country who has firms producing the product will have to allocate supply throughout all the preferential trade area, and may more experience capacity constraints when supply to the whole region is taken into account. Another reason we could have an upward sloping supply curve is that the tariff protection of the Free Trade Area induces new firms and industries within the Free Trade Area to develop under the preferential tariff protection. These industries may not have been profitable without the preferential protection. We have drawn the supply curve such that within the range of tariff changes contemplated, there is not a full displacement of rest of world supply. In the case of upward sloping supply curve of the partner country, without full displacement of rest of world supply, the price in country A will increase by the full amount of the tariff. ${ }^{12}$

In the event that partner country supply is not upward sloping for some products (that is, partner country supply is flat due to constant costs within the range of relevant outputs) the

12 Effective cartel pricing among producers within the customs union would also imply that they will raise prices in response to the increase in the tariff, but in that case we could not depict a supply curve and the price increase would not necessarily equal the increase in the tariff. Partner producers could price as a dominant cartel subject to a competitive fringe, where rest of world supply is the competitive fringe. 
welfare economics of participating in customs unions and free trade agreements will be less disadvantageous. ${ }^{13}$ It is likely that for some products imported within the potential customs union, there are constant costs for partner country suppliers, and for others products there are increasing costs as depicted in figure 1 . Thus, the welfare costs of participating in the customs union are likely to be somewhat less than would be indicated from reliance solely on the analysis of figure 1.

\section{Initial Equilibrium: A Non-Preferential Ad-Valorem Tariff}

We begin with the situation that prevailed prior to the Free Trade Agreement: a tariff rate at rate $t$ is applied on all imports. That is, there are no Free Trade Agreements with any countries, i.e., no tariff preferences for customs union members or others. In the initial equilibrium, the external tariff is $t$, the price of imports from the rest of the world to consumers in country $A$ is $P_{R}(1+t)$. Thus, the quantity demanded of imports is $M_{0}$. Country $A$ consumers must pay the same tariff inclusive price to future partner country suppliers, so the price paid for their products may be read off their tariff ridden supply curve $S_{P} /(1+t)$, i.e., $Q_{0}$. Rest of world suppliers supply the quantity $M_{0}-Q_{0}$. Tariff revenue is obtained on all imports, so initial tariff revenue equals the area MIAD. The tariff revenue is decomposed into SRAD obtained on imports from rest of world suppliers and SRIM on imports from future partner country suppliers.

The short-run static welfare losses of the tariff are equal to the triangle ADL. Consumers in country A must pay the higher price $P_{R}(1+t)$, rather than $P_{R}$, and thus there is a loss of consumers' surplus equal to the trapezoid MIAL. But, since the government recovers the area MIAD in tariff revenue, this area is not a loss to the economy. On the other hand, he area ADL is a loss to the economy: it represents consumption inefficiency loss as consumers in country A shift purchases from imports of this good to goods that they preferred less before the tariff.

13. The original analysis of Viner (1950) considered constant costs for partner countries. Both trade creation and trade diversion are possible in the constant cost case. See Bhagwati and Panagariya (1996) for a general treatment of the various cases. 


\section{The Impact of the Free Trade Agreement}

Now consider the impact of participating in a Free Trade Agreement, given a tariff rate of $t$ on imports from the rest of the world. Since the external tariff is unchanged at rate $t$, the price of imports from the rest of the world to consumers into country $A$ remains unchanged at $P_{R}(1+t)$. Thus, the quantity demanded of imports remains $\mathbf{M}_{\mathbf{O}}$. Since imports from partner countries are not subject to the tariff, supply from partner countries shifts out and to the right to the supply curve $S_{P}$. Consumers in country A must pay the same price to partner countries suppliers, so the price paid for their products may be read off their supply curve $S_{P}$, i.e., $Q_{0}{ }^{*}$. Rest of world suppliers

supply the quantity $M_{0}-Q_{0}{ }^{*}$. The government obtains tariff revenue on the imports from the rest of the world, equal to the rectangle GHAD, but imports from partner countries enter without paying tariffs.

What is the welfare economics of the Free Trade Agreement, compared to the initial equilibrium with non-preferential tariffs at rate $t$ on all imports? A tariff at the rate $t$ still induces a loss of consumer surplus equal to the trapezoid MIAL, but again not all of this is a loss to the economy. The area ADL remains as a loss to the economy, representing consumption inefficiency loss. The area of tariff revenue GHAD, however, is recaptured by the government, so does not represent a loss to the economy. On the other hand, the shaded area MIHG is a loss to country A due to the Free Trade Agreement. This area is a loss to country A because it is paying higher prices to partner suppliers on the quantity $Q_{0}$ compared to what country A would have to pay from rest of the world suppliers. Part of this higher payment for partner country imports (the trapezoid MNHI) is captured by partner country suppliers as producers' surplus. But part of the higher prices paid by country A consumers is pure inefficiency loss, i.e., producers' deadweight loss equal to NGH, because the preferential tariff induces additional supply from partner country suppliers who are marginally inefficient compared to world suppliers. The net change in welfare to the government of the Free Trade Agreement, given no change in tariffs to the rest of the world, is a loss equal to the rectangle MIHG. The combined loss of the tariff and the Free Trade Agreement is the sum of the areas ADL and MIHG. 
In summary, a tariff will induce inefficiency losses, but the Free Trade Area with partners with upsloping supply curves greatly magnifies the losses. With a non-preferential tariff of $t$, the economy loses only the triangle of consumption inefficiency loss, ADL. The Free Trade Area increases the losses due to the tariff in the amount of MIHG. This explains why preferential trade arrangements with small partner countries or with countries that may be expected to increase supply at higher protected prices can be expected to be very inefficient, more inefficient than nonpreferential tariff protection.

Weighed against these costs are the benefits obtained from increased access to partner country markets. There will likely be a terms of trade gain on these exports, since exports have preferential tariff protection against rest of world supply. Producers' surplus to the exporters from country A within the Free Trade Area (not depicted) would reduce the losses from the Free Trade Area. We have argued above, however, that the gain on exports is likely to be less than the losses on imports.

\section{Converting the Free Trade Area to a Customs Union}

Now consider the impact of imposing the common external tariff at the rate $t^{\prime}$, starting from the Free Trade Agreement in place. The supply curve including the tariff of the rest of the world and the new equilibrium price increases to $P_{R}\left(1+t^{\prime}\right)$, where the quantity demanded for imports declines to $M_{1}$. Partner country suppliers also receive this higher price and then the quantity they supply increases to $Q_{1}$. The quantity supplied from the rest of the world declines to $\mathrm{M}_{1}-\mathrm{Q}_{1}$.

The welfare costs to country A are strongly negative, and may be decomposed into three parts. First, there are consumer deadweight losses because country A consumers are induced to reduce their consumption of total imports from $M_{0}$ to $M_{1}$ in favor of alternate goods available that were previously less preferred (this could include domestic substitutes in this product category or goods in other product categories). These were equal to the triangle ADL in the initial equilibrium, but they increase to $B C L$. The difference is the shaded area $A B C D$, representing the 
increase in consumers' deadweight loss due to the common external tariff. Second, there is an increase in the triangle of producers' deadweight losses, from NGH to NFE. The difference is the shaded area FEHG, representing the increase in producers' deadweight loss due to the imposition of the common external tariff. Partner country producers are able to obtain higher prices in country A, which attracts less efficient higher cost supply. Absent a tariff, supplies from the rest of the world would have been available at the price $P_{R}$. Third, part of the higher prices received by partner country suppliers results in an increase in their profits or producers' surplus. The increase in partner country profits or producers surplus is HIJE; this is a transfer from country A consumers to producers in partner countries.

Overall the loss of moving to the customs union, given that a Free Trade Agreement is already in place, is the sum of the three shaded areas in figure 1: ABCD + FEHG + HIJE. The losses to the economy of increasing tariffs through the common external tariff of the customs union, given a Free Trade Agreement, are considerably greater than non-preferential tariff increases from an average rate of $t$ to $t$ '. That is, if tariffs were applied in a non-preferential manner and were increased from $t$ to $t^{\prime}$, the costs to the economy of the increase in the tariff would be the shaded area ABCD. The customs union imposes the additional costs equal to the areas FEHG and HIJE, representing inefficiency losses and transfers to partner country suppliers, respectively.

\section{Combined Loss of the Customs Union and the Free Trade Agreement}

The combined loss of the Free Trade Agreement and the customs union is larger than the loss of the customs union or the Free Trade Agreement alone and equals the triangle BCL plus the rectangle MFEJ. A non-preferential tariff of rate $t$ ' would produce a welfare loss equal to the triangle BCL. The difference is equal to the area MFEJ which derives from the fact that consumers in country A pay higher prices to partner country producers than they would have to pay to rest of the world producers. The area MFEJ would be captured for country A as tariff revenue and not lost to the economy if the tariff were not preferential. Instead with a the 
combination Free Trade Agreement and customs union the area MFEJ is added to the losses of country A, thereby greatly magnifying the losses. The area MFEJ represents a combination of transfers to partner country suppliers (the area MNEJ) plus inefficiency (deadweight) losses of using marginally inefficient partner country suppliers (the triangle NFE). It is necessary to reduce this estimate of the losses by the increase in the terms of trade earned by exporters from country A on their sales within the PTA. Since the tariff primarily benefits existing Customs Union members, these gains may be expected to be small.

\section{Conclusion}

A tariff will induce inefficiency losses, but preferential trading areas with partners with upsloping supply curves greatly magnify the losses. This explains why preferential trade ' arrangements with small partner countries or with countries that may be expected to increase supply at higher protected prices can be expected to be very inefficient, more inefficient than nonpreferential tariff protection at the same rate. 


\section{References}

Berglas, Eitan (1981), "Harmonization of Commodity Taxes: Destination, Origin and Restricted Origin Principles," Journal of Public Economics, 16, pp. 377-387.

Bhagwati, Jagdish and Anne Krueger (1973), Exchange Control, Liberalization and Economic Development, American Economic Review, 63 (2), May, 419-427.

Bhagwati, Jagdish and Arvind Panagariya (1996), "Preferential Trading Areas and Multilateralism: Strangers, Friends or Foes," in J. Bhagwati and A. Panagariya (eds.), The Economics of Preferential Trade Agreements, Washington D.C.: AEI Press.

Brecher, Richard and Carlos Diaz-Alejandro (1977), "Tariffs, Foreign Capital and Immiserizing Growth," Journal of International Economics, 7, 317-322.

Coe, D.T. and E. Helpman (1995), “International R\&D Spillovers," European Economic Review, $39(5), 859-887$.

Coe, D.T., E. Helpman and A.W. Hoffmaister (1995), "North-South R\&D Spillovers, "Centre for Economic Policy Research, Discussion Paper No. 1275.

Grossman, Gene and Elhanin Helpman (1995), The Politics of Free-Trade Agreements, The American Economic Review, 85 (4), 667-690.

Matusz, Stephen (1997), Adjusting to Trade Liberalization, background paper for the Global Economic Prospects, 1997, mimeo, International Economics Department, The World Bank.

Melo, Jaime de, Arvind Panagariya and Dani Rodrik (1993), "The New Regionalism: A Country Perspective" in Melo, Jaime de and Arvind Panagariya (eds.), New Dimensions in Regional Integration, Cambridge University Press.

Michalopoulos, Constantine and David Tarr (1996), Trade Policy and Performance Among the Newly Independent States, Directions in Development Series, Washington D.C.: The World Bank.

Michalopoulos, Constantine and David Tarr, eds. (1994), Trade in the New Independent States, Studies of Economies of Transition No. 13, Washington D.C.: The World Bank, UNDP.

Michalopoulos, Constantine and David Tarr (1993), Energizing Trade Among the States of the former USSR, Finance and Development, March.

Michalopoulos, Constantine and David Tarr (1992), Trade and Payments Arrangements for States of the former USSR, Studies of Economies of Transition No. 2, Washington D.C.: The World Bank. 
Morkre, Morris and David Tarr (1980), Effects of Restriction on United States Imports: Five Case Studies and Theory, Bureau of Economics, Federal Trade Commission, Washington D.C.

Romer, Paul (1994), New Goods, Old Theory and the Welfare Costs of Trade Restrictions, Journal of Development Economics, 43, 5-38.

Rutherford, Thomas and David Tarr (1996), "Blueprints, Spillovers and the Dynamic Gains from Trade Liberalization in a Small Open Economy," in Richard Baldwin and Joseph Francois (eds.), Dynamic Issues in Applied Commercial Policy Analysis, CEPR conference volume, forthcoming.

Rietzler, Katja and Usmanova, Fabra, "Prospects for Export Led Growth in Kazakstan", Kazakstan Economic Trends, Second Quarter, Almaty 1996.

Sachs, Jeffrey and Andrew Warner (1995), "Economic reform and the Process of Global Integration," in W. Brainard and G. Perry (eds.) Brookings Papers on Economic Activity, pp. 1-117.

Thomas, Vinod, John Nash and others (1991), Best Practices in Trade Policy Reform, New York: Oxford University Press.

Viner, Jacob (1950), The Customs Union Issue, New York: Carnegie Endowment for International Peace.

Winters, L. Alan (1996), “Lebanon's Euro-Mediterranean Agreement: Possible Dynamic Benefits," mimeo, International Economics Department, The World Bank.

c: $|k y r| k y r c u 9 . d o c$ 
TABLE 1. Foreign Trade of the New Independent States with Each Other 1991-95

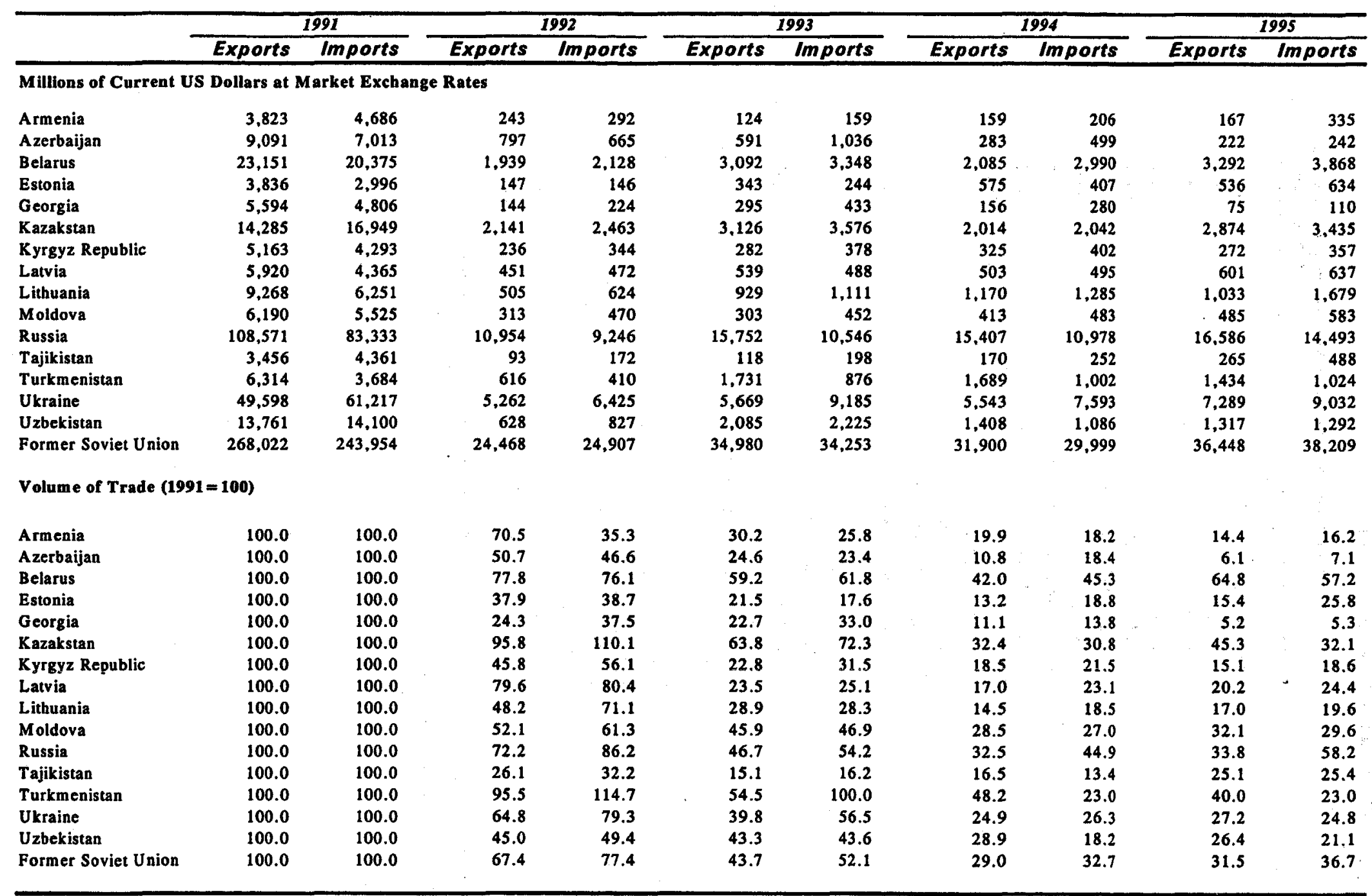

SOURCES: IMF Direction of Trade Statistics, 1995 Annual for the following countries and periods: Armenia 1994-95; Azerbaijan 1992-95;

Estonia 1993-95; Latvia 1993-95; Lithuania 1994-95; Moldova 1992-95; Russia 1994-95, Ukraine 1994-95. For all other countries and periods, national official statistics and World Bank staff estimates were used. For further information on sources and methods, see Michalopoulos, $C$. and

D. Tarr, Trade in the New Independent States, 1994. Studies of Economies in Transformation No. 13. World Bank, Chapter 1 and Appendix; Belkindas, M. and O.V. Ivanova, Foreign Trade Statistics in the USSR and Successor States, 1996. Studies of Economies in Transformation No. 18. World Bank, Chapter 8. 
Table 2: Tariff Rates of the Russian Federation

\begin{tabular}{lr}
\hline Sectors & Unweighted \\
\hline & \\
Food manufacturing & 14.7 \\
Beverages & 23.1 \\
Tobacco & 7.5 \\
Textiles & 16.4 \\
Wearing apparel & 24.1 \\
Leather products & 9.7 \\
Footwear & 20.0 \\
Wood, cork, and products & 17.5 \\
Wooden furniture \& fixtures & 24.7 \\
Paper products & 14.2 \\
Printing \& publishing & 12.5 \\
Industrial chemicals & 5.7 \\
Other chemical products & 7.4 \\
Petroleum refineries & 5.0 \\
Petroleum \& coal products & 9.0 \\
Rubber products & 6.0 \\
Plastic products nec. & 13.8 \\
Ceramic products & 22.9 \\
Glass \& glass products & 14.5 \\
Other nonmetal min prods & 15.8 \\
Iron \& steel B-met ind & 5.6 \\
Nonferrous B-met ind & 13.1 \\
Metal products nec & 18.8 \\
Nonelectric machinery & 12.4 \\
Electrical machinery & 10.1 \\
Transport equipment & 16.6 \\
Scientific equipment & 15.7 \\
Other manufacturing & 20.5 \\
& \\
\hline \hline & \\
\hline
\end{tabular}

Source: World Bank estimates for 1996. 


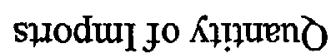

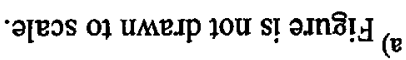

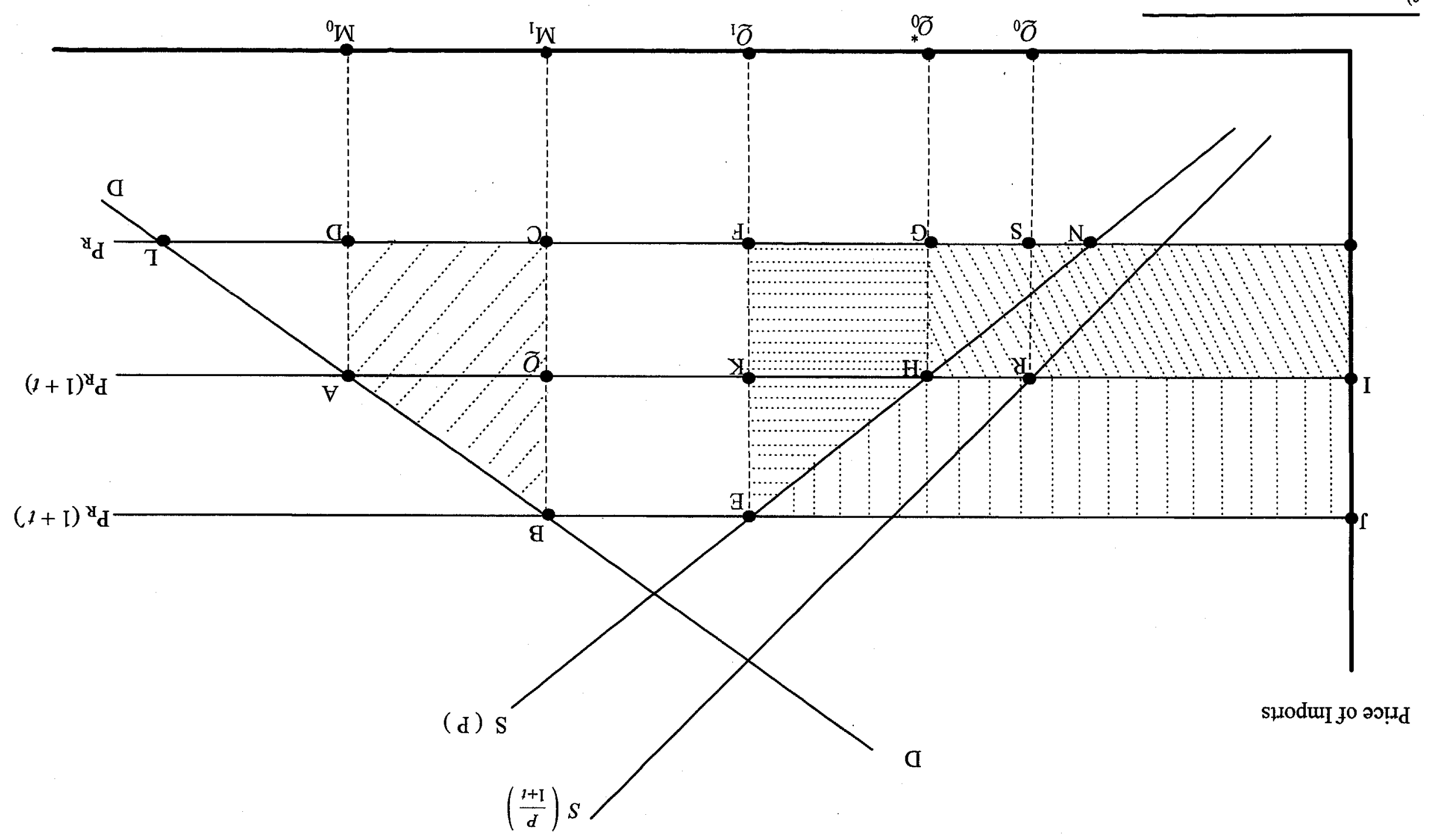

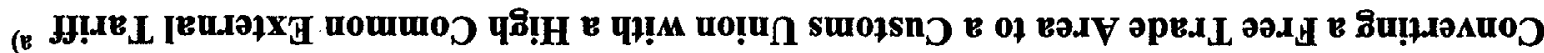


Policy Research Working Paper Series

\begin{tabular}{|c|c|c|c|c|}
\hline & Title & Author & Date & $\begin{array}{l}\text { Contact } \\
\text { for paper }\end{array}$ \\
\hline WPS1760 & $\begin{array}{l}\text { Credibility of Rules and Economic } \\
\text { Growth: Evidence from a Worldwide } \\
\text { Survey of the Private Sector }\end{array}$ & $\begin{array}{l}\text { Aymo Brunetti } \\
\text { Gregory Kisunko } \\
\text { Beatrice Weder }\end{array}$ & April 1997 & $\begin{array}{l}\text { M. Geller } \\
31393\end{array}$ \\
\hline WPS1761 & $\begin{array}{l}\text { Bending the Rules: Discretionary } \\
\text { Pollution Control in China }\end{array}$ & $\begin{array}{l}\text { Susmita Dasgupta } \\
\text { Mainul Huq } \\
\text { David Wheeler }\end{array}$ & May 1997 & $\begin{array}{l}\text { E. de Castro } \\
89121\end{array}$ \\
\hline WPS1762 & $\begin{array}{l}\text { Strategies for Pricing Publicly } \\
\text { Provided Health Services }\end{array}$ & $\begin{array}{l}\text { Paul J. Gertler } \\
\text { Jeffrey S. Hammer }\end{array}$ & May 1997 & $\begin{array}{l}\text { C. Bernardo } \\
31148\end{array}$ \\
\hline WPS1763 & $\begin{array}{l}\text { China and the Multilateral Investment } \\
\text { Guarantee Agency }\end{array}$ & Yushu Feng & May 1997 & $\begin{array}{l}\text { E. Beers } \\
36175\end{array}$ \\
\hline WPS1764 & $\begin{array}{l}\text { A Reversal of Fortune for Korean } \\
\text { Women: Explaining } 1983 \text { 's Upward } \\
\text { Turn in Relative Earnings }\end{array}$ & $\begin{array}{l}\text { Yaba vab der Neykeb } \\
\text { Rodgers }\end{array}$ & May 1997 & $\begin{array}{l}\text { D. Ballantyne } \\
87198\end{array}$ \\
\hline WPS1765 & $\begin{array}{l}\text { Explaining Agricultural and Agrarian } \\
\text { Policies in Developing Countries }\end{array}$ & $\begin{array}{l}\text { Hans P. Binswanger } \\
\text { Klaus Deininger }\end{array}$ & May 1997 & $\begin{array}{l}\text { D. Housden } \\
36637\end{array}$ \\
\hline WPS1766 & $\begin{array}{l}\text { New Systems for Old Age Security: } \\
\text { Theory, Practice, and Empirical } \\
\text { Evidence }\end{array}$ & Estelle James & May 1997 & $\begin{array}{l}\text { S. Khan } \\
33651\end{array}$ \\
\hline WPS1767 & $\begin{array}{l}\text { Pension Reform: Is There a Tradeoff } \\
\text { between Efficiency and Equity? }\end{array}$ & Estelle James & May 1997 & $\begin{array}{l}\text { S. Khan } \\
33651\end{array}$ \\
\hline WPS1768 & $\begin{array}{l}\text { Is There a Quantity-Quality Tradeoff } \\
\text { as Enrollments Increase? Evidence } \\
\text { from Tamil Nadu, India }\end{array}$ & $\begin{array}{l}\text { P. Duraisamy } \\
\text { Estelle James } \\
\text { Julia Lane } \\
\text { Jee-Peng Tan }\end{array}$ & May 1997 & $\begin{array}{l}\text { S. Khan } \\
33651\end{array}$ \\
\hline WPS1769 I & $\begin{array}{l}\text { Information, Incentives, and } \\
\text { Commitment: An Empirical Analysis } \\
\text { of Contracts between Government } \\
\text { and State Enterprises }\end{array}$ & $\begin{array}{l}\text { Mary M. Shirley } \\
\text { L. Colin Xu }\end{array}$ & May 1997 & $\begin{array}{l}\text { P. Sintim-Aboagye } \\
38526\end{array}$ \\
\hline $\begin{aligned} & \text { WPS1770 F } \\
& \text { in }\end{aligned}$ & $\begin{array}{l}\text { Poverty and Social Transfers } \\
\text { in Hungary }\end{array}$ & Christiaan Grootaert & May 1997 & $\begin{array}{l}\text { G. Ochieng } \\
31123\end{array}$ \\
\hline WPS1771 C & $\begin{array}{l}\text { Government Employment and Pay: } \\
\text { A Global and Regional Perspective }\end{array}$ & $\begin{array}{l}\text { Salvatore Schiavo-Campo } \\
\text { Giulio de Tommaso } \\
\text { Amitabha Mukherjee }\end{array}$ & May 1997 & $\begin{array}{l}\text { A. Panton } \\
85433\end{array}$ \\
\hline $\begin{array}{r}\text { WPS1772 V } \\
\text { S }\end{array}$ & $\begin{array}{l}\text { What Drives Deforestation in the } \\
\text { Brazilian Amazon? Evidence from } \\
\text { Satellite and Socioeconomic Data }\end{array}$ & Alexander S. P. Pfaff & May 1997 & $\begin{array}{l}\text { A. M. Maranon } \\
39074\end{array}$ \\
\hline
\end{tabular}




\section{Policy Research Working Paper Series}

Title

WPS1773 The Costs and Benefits of Regulation: Implications for Developing Countries

WPS1774 The Demand for Base Money and the Sustainability of Public Debt

WPS1775 Can High-Inflation Developing
Countries Escape Absolute Poverty?

WPS1776 From Prices to Incomes: Agricultural Subsidization Without Protection?

WPS1777 Aid, Policies, and Growth

WPS1778 How Government Policies Affect the Relationship between Polish and World Wheat Prices

WPS1779 Water Allocation Mechanisms: Principles and Examples

WPS1780 High-Level Rent-Seeking and Corruption in African Regimes: Theory and Cases

WPS1781 Technology Accumulation and Diffusion: Is There a Regional Dimension?

WPS1782 Regional Integration and the Prices of Imports: An Empirical Investigation

WPS1783 Trade Policy Options for the Chilean Government: A Quantitative Evaluation

WPS1784 Analyzing the Sustainability of Fiscal Deficits in Developing Countries

WPS1785 The Causes of Government and the Consequences for Growth and Well-Being
Author

Date

J. Luis Guasch

Robert W. Hahn

Valeriano F. Garcia

June 1997

Martin Ravallion

John Baffes

Jacob Meerman

Craig Burnside

David Dollar

Szczepan Figiel

Tom Scott

Panos Varangis

Ariel Dinar

Mark W. Rosegrant

Ruth Meinzen-Dick

Jacqueline Coolidge

Susan Rose-Ackerman

Pier Carlo Padoan

June 1997

June 1997

L. Alan Winters

Won Chang

Glenn W. Harrison

June 1997

Thomas F. Rutherford

David G. Tarr

John T. Cuddington

Simon Commander

Hamid R. Davoodi

Une J. Lee

June 1997

June 1997

June 1997
Contact

for paper

J. Troncoso 38606

J. Forgues 39774

$\begin{array}{ll}\text { June } 1997 & \begin{array}{l}\text { P. Sader } \\ 33902\end{array} \\ \text { June } 1997 & \begin{array}{l}\text { P. Kokila } \\ 33716\end{array} \\ \text { June 1997 } & \begin{array}{l}\text { K. Labrie } \\ 31001\end{array} \\ \text { June 1997 } & \begin{array}{l}\text { J. Jacobson } \\ 33710\end{array}\end{array}$

M. Rigaud 30344

N. Busjeet 33997

J. Ngaine 37947

J. Ngaine 37947

J. Ngaine 37947

S. King-Watson 31047

E. Witte 85637 